\title{
Fludarabine modulates composition and function of the $T$ cell pool in patients with chronic lymphocytic leukaemia
}

\author{
Franz Josef Gassner · Lukas Weiss · Roland Geisberger · Josefina Piñón Hofbauer • \\ Alexander Egle $\cdot$ Tanja Nicole Hartmann $\cdot$ Richard Greil $\cdot$ Inge Tinhofer
}

Received: 23 December 2009 / Accepted: 6 September 2010 / Published online: 21 September 2010

(C) The Author(s) 2010. This article is published with open access at Springerlink.com

\begin{abstract}
The combination of cytotoxic treatment with strategies for immune activation represents an attractive strategy for tumour therapy. Following reduction of high tumour burden by effective cytotoxic agents, two major immune-stimulating approaches are being pursued. First, innate immunity can be activated by monoclonal antibodies triggering antibody-dependent cellular cytotoxicity. Second, tumour-specific $\mathrm{T}$ cell responses can be generated by immunization of patients with peptides derived from tumour antigens and infused in soluble form or loaded onto dendritic cells. The choice of cytotoxic agents for such combinatory regimens is crucial since most substances such as fludarabine are considered immunosuppressive while others such as cyclophosphamide can have immunostimulatory activity. We tested in this study whether fludarabine and/or cyclophosphamide, which represent a very effective treatment regimen for chronic lymphocytic leukaemia,
\end{abstract}

R. Greil, I. Tinhofer contributed equally to this work.

Electronic supplementary material The online version of this article (doi:10.1007/s00262-010-0920-3) contains supplementary material, which is available to authorized users.

F. J. Gassner · L. Weiss · R. Geisberger · J. P. Hofbauer · A. Egle · T. N. Hartmann $\cdot$ R. Greil $(\bowtie) \cdot$ I. Tinhofer

Laboratory for Immunological and Molecular Cancer Research

(LIMCR), 3rd Medical Department with Haematology,

Medical Oncology, Haemostaseology, Rheumatology

and Infectiology, Paracelsus Medical University Salzburg,

Muellner Hauptstrasse 48, 5020 Salzburg, Austria

e-mail: r.greil@salk.at

I. Tinhofer

Translational Radiobiology and Radiooncology Research

Laboratory, Clinical Department for Radiotherapy (CCM/CVK),

Charité University Hospital Berlin, Berlin, Germany would interfere with a therapeutic strategy of T cell activation. Analysis of peripheral blood samples from patients prior and during fludarabine/cyclophosphamide therapy revealed rapid and sustained reduction of tumour cells but also of $\mathrm{CD}^{+}$and $\mathrm{CD}^{+} \mathrm{T}$ cells. This correlated with a significant cytotoxic activity of fludarabine/cyclophosphamide on $\mathrm{T}$ cells in vitro. Unexpectedly, $\mathrm{T}$ cells surviving fludarabine/cyclophosphamide treatment in vitro had a more mature phenotype, while fludarabine-treated $\mathrm{T}$ cells were significantly more responsive to mitogenic stimulation than their untreated counterparts and showed a shift towards $\mathrm{T}_{\mathrm{H}} 1$ cytokine secretion. In conclusion, fludarabine/cyclophosphamide therapy though inducing significant and relevant $\mathrm{T}$ cell depletion seems to generate a micromilieu suitable for subsequent $\mathrm{T}$ cell activation.

Keywords Fludarabine - CLL · Immunomodulation . $\mathrm{T}$ cells

\section{Introduction}

In general, the success or failure of cancer immunotherapy depends on whether efficient stimulation of $\mathrm{T}$ cells and subsequent establishment of an activated, tumour-specific memory $\mathrm{T}$ cell pool is accomplished or not. While our knowledge of the biology of tumour cells, antigen-presenting cells and their complex interactions with autologous $\mathrm{T}$ cells increases, the challenges regarding clinical efficacy of immunotherapy remain to be resolved [1-6]. Among them are the rather low frequency of tumour antigen-specific $\mathrm{T}$ cells, their limited life span and their loss of cytolytic activity in vaccination studies [7]. It can also be expected that the efficiency of $\mathrm{T}$ cell activation following vaccination is generally reduced in patients with intrinsic $\mathrm{T}$ cell deficiencies. 
In chronic lymphocytic leukaemia (CLL), changes within the $\mathrm{T}$ cell compartment comprise abnormal increase in absolute $\mathrm{CD}^{+}$and $\mathrm{CD} 8^{+} \mathrm{T}$ cell numbers with abnormal phenotype, such as increase in death receptor expression [8], loss of costimulatory molecules necessary for stimulation of antigen-presenting cells [9], abnormal cytokine/ receptor profile [10], impaired formation of the immune synapse [11] as well as accumulation of regulatory $\mathrm{T}$ cells (Treg) $[12,13]$. All these alterations might contribute to the decreased responsiveness of $T$ cells to antigenic stimulation and to the hypogammaglobulinaemia observed in CLL patients, making them highly susceptible to severe opportunistic infections [14]. In addition, it might allow unhindered expansion of the tumour clone in phases of disease progression or tumour relapse following therapy.

A combination of two agents, the nucleoside analogue fludarabine, and cyclophosphamide, a DNA-alkylating agent, has been shown to be a highly effective treatment for CLL patients [15-17]. Efficacy can even be improved by combining fludarabine/cyclophosphamide with additional therapeutics like mitoxantron [18] or monoclonal antibodies like rituximab [19-21]. It has already been shown that cyclophosphamide, beside being cytoreductive, is able to enhance lymphocyte reconstitution and immune responses (for review [3, 22]), whereas fludarabine is routinely administered in the setting of allogeneic stem cell transplantation and leads to prolonged immunosuppression [23]. The aim of our study was to characterize activation status, subset distribution and functions of the T cell compartment from CLL patients after treatment with fludarabine, cyclophosphamide or both.

\section{Materials and methods}

\section{Patients}

The study was conducted according to the Declaration of Helsinki. After obtaining informed patient consent, untreated CLL patients seen at the Department of Haematology and Oncology, University Hospital Salzburg, Austria between January 2005 and April 2010 were included in this study. Peripheral blood mononuclear cells (PBMCs) were collected in heparinized or EDTA-coated tubes during routine examinations. CLL was defined by clinical criteria as well as by cellular morphology and the coexpression of CD19, CD5, and CD23 in lymphocytes simultaneously displaying restriction of light-chain rearrangement. Staging was performed according to modified Rai classification [24]. Characteristics of the patients studied are presented in Table 1. For those experiments where not all patients were included, the patient samples were unselected.
Table 1 Patient characteristics

\begin{tabular}{ll}
\hline Parameters & $\begin{array}{l}\text { No. of } \\
\text { patients }(\%)\end{array}$ \\
\hline $\begin{array}{l}\text { Total number } \\
\text { Sex }\end{array}$ & $55(100)$ \\
Male & $35(64)$ \\
Female & $20(36)$ \\
Age (years) & \\
Median & 72 \\
Range & $47-94$ \\
Duration of disease (years) & \\
Median & 5.7 \\
Range & $1.75-27.1$ \\
Rai stage & \\
Low (0) & $23(42)$ \\
Intermediate (I/II) & $27(49)$ \\
High (III/IV) & $5(9)$ \\
Molecular risk parameters & \\
Unmutated Ig VH & $15(29)($ nda: 4$)$ \\
Unfavourable genetic & $2(4)(\mathrm{nda}: 1)$ \\
aberration(s) (del17p, 11q) & \\
CD38 + B-CLL ( $\geq 30 \%)$ & $15(29)(\mathrm{nda}: 3)$ \\
\hline$B-C L L$ B celchroniclymphocyc &
\end{tabular}

$B$ - $C L L$ B cell chronic lymphocytic leukaemia, $I g$ immunoglobulin, $V H$ variable heavy chain, $n d a$ no data available

Purification of PBMC and cell culture

Peripheral blood mononuclear cells were separated by density centrifugation. Fresh blood samples were diluted 1:1 with RPMI 1640 (PAA Laboratories, Pasching, Austria) and layered over Biocoll separating solution (Biochrom AG, Berlin, Germany). The opaque layer on top of the Biocoll-containing PBMCs was collected, washed once with phosphate-buffered saline (PBS) and resuspended in complete medium [RPMI 1640 medium containing $2 \mathrm{mM}$ L-glutamine, $100 \mathrm{U} / \mathrm{ml}$ penicillin/streptomycin and $10 \%$ fetal calf serum (FCS)]. PBMCs were then incubated at $37^{\circ} \mathrm{C}$ and $5 \% \mathrm{CO}_{2}$ for $24 \mathrm{~h}$ in medium alone or in presence of $1 \mu \mathrm{g} / \mathrm{ml}$ fludarabine (Sigma-Aldrich, MO, USA), $1 \mu \mathrm{g} / \mathrm{ml}$ mafosfamide (IIT GmbH, Bielefeld, Germany), or a combination of both. PBMCs were then washed and cultured for up to 6 days in complete medium.

Flow cytometry analysis

For characterization of the T cell pool, fresh blood samples or purified PBMCs were incubated for 15 min with a mixture of fluorochrome-labelled murine anti-human antibodies directed to the following antigens: CD19 (R-phycoerythrin, $\mathrm{RPE}$ ), CD25 [fluorescein isothiocyanate (FITC)] (all from BD Biosciences, CA, USA), CD3 (phycoerythrin-cyanin 5, PC5), 
CD4 [(energy-coupled dye (ECD)], CD4 (phycoerythrincyanin 7, PC7), CD8 (PC7), CD19 (PC7), CD38 (PE), CD45RA (FITC), CD45RA (ECD), CD62L (PE), CD127 (PE) (all from Beckman Coulter, CA, USA), CD4 (cyanin 5, Cy5), CD8 (FITC), CD8 (PC5) (all from DAKO, Glostrup, Denmark). Viability was assessed by staining cells with Annexin-V (FITC) (Alexis, Lausen, Switzerland) and 7-AAD (Beckman Coulter). Subsequently, samples were washed with PBS and analyzed immediately using the FC500 flow cytometer and the CXP1.0 software (Beckman Coulter).

For characterization of murine $\mathrm{T}$ cells, tail vein blood was stained with fluorochrome-labelled rat anti-mouse antibodies directed to the following antigens: CD3 (FITC), CD25 (PE), CD44 (cyanin 5.5), CCR4 (PC7), CXCR3 (Allophycocyanin; APC), CD4 (Pacific Blue) (all from BioLegend Europe, Uithoorn, the Netherlands) and CD8 (APC-H7) (BD Biosciences) for $15 \mathrm{~min}$. Erythrocytes were lysed using BD FACS Lysing solution (BD Biosciences). Cells were then resuspended in PBS and analysed immediately using the Gallios flow cytometer (Beckman Coulter).

Allogeneic dendritic cell preparation and mixed lymphocyte reaction

Peripheral blood mononuclear cells were purified by density centrifugation from buffy coats from healthy donors retrieved from the local blood bank. Monocytes were enriched by CD14 MicroBead-positive selection (Miltenyi, Bergisch Gladbach, Germany) and cultivated in complete medium in the presence of recombinant human interleukin 4 (rhIL-4,500 U/ml) and granulocyte macrophage colonystimulating factor (rhGM-CSF, 1,000 U/ml) (both from CellGenix, Freiburg, Germany) for 6 days. Fresh rhIL-4 and rhGM-CSF was added on day 3 . On day 6 , purity of differentiated dendritic cells was assessed by light microscopy and by flow cytometry (CD14-Cy5, CD11c-PE, CD83-FITC; Beckman Coulter). Cultures containing $>90 \%$ dendritic cells, displaying high expression of CD11c and low expression of CD14 and CD83, were irradiated with $30 \mathrm{~Gy}$ and stored at $-80^{\circ} \mathrm{C}$ until used.

Mixed lymphocyte reaction (MLR) was performed using CLL PBMCs as responders and allogeneic dendritic cells from six different buffy coats as stimulators. In brief, PBMCs from CLL patients were incubated for $24 \mathrm{~h}$ with fludarabine $(1 \mu \mathrm{g} / \mathrm{ml})$ or medium alone. The cells were then washed with PBS. Irradiated allogeneic dendritic cells were thawed and viability was assessed by trypan blue inclusion. CLL PBMCs and allogeneic dendritic cells were incubated with $5 \mu \mathrm{M} 5(6)$-carboxyfluorescein diacetate $N$-succinimidyl ester (CFSE, Sigma, MO, USA) at a concentration of $10^{6}$ cells $/ \mathrm{ml}$ in PBS for $5 \mathrm{~min}$. CFSE incorporation was stopped by adding complete medium and the cells were washed once with complete medium. PBMCs from CLL patients were seeded into 24-well flat-bottom cell culture plates (Corning, MA, USA) at a concentration of $2.5 \times 10^{6}$ cells/ml/well. Irradiated CFSE-stained allogeneic dendritic cells were added at a stimulator/responder ratio of 1:10 and the coculture left untreated for 6 days. Using flow cytometry the extent of proliferation was determined at the end of the coculture period by assessing the fraction of cells which had lost incorporated CFSE upon cell division and therefore displayed reduced CFSE fluorescence intensity. In some experiments, instead of allogeneic dendritic cells polystyrene beads coated with a mixture of monoclonal antibodies against CD3 and CD28 (Dynabeads ${ }^{\circledR}$ Human CD3/CD28 T Cell Expander, Invitrogen, CA, USA) were added to the 6-day PBMC culture in a PBMC/bead ratio of 250:1.

Cytokine release measurement by cytometric bead array

Peripheral blood mononuclear cells from CLL patients were incubated for $24 \mathrm{~h}$ with fludarabine $(1 \mu \mathrm{g} / \mathrm{ml})$, mafosfamide (the active form of cyclophosphamide $1 \mu \mathrm{g} / \mathrm{ml}$ ) or a combination of both. The cells were then washed, $5 \times 10^{6}$ PBMC were incubated either with medium alone or stimulated with phorbol 12-myristate 13-acetate (PMA $1 \mathrm{ng} / \mathrm{ml})$ and ionomycin $(0.5 \mu \mathrm{g} / \mathrm{ml})$ (Sigma) for 6 days. After the stimulation period, the culture supernatants were collected and either immediately analyzed for presence of cytokines or stored at $-20^{\circ} \mathrm{C}$ for later analysis.

For evaluation of $\mathrm{T}_{\mathrm{H}} 1$ and $\mathrm{T}_{\mathrm{H}} 2$ cytokine production after stimulation, we performed cytokine bead assays (CBAs) according to the manufacturer's recommendations (CBA Human $\mathrm{T}_{\mathrm{H}} 1 / \mathrm{T}_{\mathrm{H}} 2$ Cytokine Kit II; BD Biosciences).

Murine tclltg tumour transplantation model

A tclla transgenic (tcl1tg) mouse, which has the coding region of human tclla placed under the control of a B cellspecific IgVH-promoter and $\operatorname{IgH}-\mathrm{E} \mu$ enhancer was previously published as a mouse model for CLL. It develops clonal CD5-positive B cell leukaemia manifested by peripheral blood lymphocytosis and splenomegaly at a median of 11 months [25-27]. These mice were backcrossed onto pure C57BL/6 background to allow transfer of primary tclltg tumour cells into immune competent (not irradiated) syngeneic wild type $\mathrm{C} 57 \mathrm{BL} / 6$ recipient mice. In the transplanted mice, the time to disease onset is shortened from 1 year to about 3 months, which vastly facilitates analysis (Hofbauer JP, Egle A, unpublished [26]). Tumour transplanted mice were treated with fludarabine (intraperitoneal injections of $35 \mathrm{mg} / \mathrm{kg} /$ day of fludarabine on 5 consecutive days) at the onset of disease (tumour load in peripheral blood $>30 \%$ ). Mice were bled from the tail vein at the indicated time points and $\mathrm{T}$ cell subsets were 
analysed. $\mathrm{CD}^{+}$and $\mathrm{CD} 8^{+}$memory cells were defined by low expression of CD25 and high expression of CD44. $\mathrm{T}_{\mathrm{H}} 1$ and $\mathrm{T}_{\mathrm{H}} 2$ cells were defined by expression of the chemokine receptors CXCR3 $\left(\mathrm{T}_{\mathrm{H}} 1\right)$ and CCR4 $\left(\mathrm{T}_{\mathrm{H}} 2\right)$.

\section{Statistical analysis}

All statistical analyses were performed using PASW Statistics 17 (SPSS Inc. IL, USA) or Graph Pad Prism 5. Boxplots show median (horizontal line in box), difference between 25th and 75th percentile (length of box) and data range (whiskers) unless stated otherwise. Outliers are marked by circles. Values in the results section are in general mean \pm standard deviation and $p$ value (paired or unpaired student's $t$ test). Graphics were created using PASW Statistics 17 and Graph Pad Prism 5.

\section{Results}

Characterization of $\mathrm{T}$ cells after cytotoxic treatment

Peripheral blood mononuclear cells from previously untreated CLL patients were isolated as described in "Materials and methods". For all in vitro experiments, we used mafosfamide, the active form of cyclophosphamide, since cyclophosphamide requires in vivo processing in the liver. Cells were incubated in medium containing clinically achieved concentrations of fludarabine (Flu $1 \mu \mathrm{g} / \mathrm{ml}$ ), mafosfamide (Maf $1 \mu \mathrm{g} / \mathrm{ml}$ ), or a combination of both agents (FluMaf) [28]. After $24 \mathrm{~h}$, cells were washed, counted and cultivated for an additional period of 6 days. Viability of $\mathrm{CD}^{+}$and $\mathrm{CD} 8^{+} \mathrm{T}$ cells and of CD19 ${ }^{+} \mathrm{CLL}$ cells was determined on day 0 and day 6 by the Annexin $V$ binding assay (Table 2). While there was no significant reduction in viability detectable immediately after the $24-\mathrm{h}$ incubation with any of the single agents, the combined
FluMaf treatment significantly reduced viability of tumour cells and T cells when compared with medium control. Six days post-treatment PBMCs showed significantly reduced viability in the $\mathrm{CD}^{+}, \mathrm{CD}^{+} \mathrm{T}$ cell as well as in the $\mathrm{CD} 19^{+}$ CLL cell compartment. We found no significant correlation of any of the investigated clinical risk parameters (Table 1) with in vitro sensitivity of $\mathrm{T}$ cells to fludarabine or mafosfamide. Additionally, we calculated the ratio between CLL cells and $\mathrm{T}$ cells before and 6 days after cytotoxic treatment. We found a significant increase in the CLL/T cell ratio (Table 2) indicating a higher sensitivity of $\mathrm{T}$ cells to cell death induced by fludarabine and mafosfamide when compared with CLL cells.

At the end of the 6-day culture period, T cells surviving cytotoxic treatment were characterized with respect to expression of the activation marker CD38, the relative distribution of naïve and memory $\mathrm{T}$ cells and the relative proportion of Tregs within the $\mathrm{T}$ cell pool. The difference in the numbers of the patient samples in Fig. 1 is based on the strong reduction in cell numbers following cytotoxic treatment in some cases that did not allow analysis. However, all statistical analyses were calculated from paired samples. We found a significant reduction in the percentage of CD38-expressing $\mathrm{CD}^{+} \mathrm{T}$ cells after treatment with mafosfamide $(26.6 \% \pm 12.8, p=.001)$ and FluMaf $(22.2 \% \pm$ 20.3, $p=.048$ ) when compared with untreated PBMCs $(38.3 \% \pm 20.4)$, while fludarabine treatment had no effect on CD38 expression $(35.6 \% \pm 24.4, p=.063)$ (Fig. 1a). In the $\mathrm{CD} 8^{+} \mathrm{T}$ cell pool, such a reduction of relative numbers of $\mathrm{CD} 38^{+} \mathrm{T}$ cells after treatment with mafosfamide or FluMaf was also observed, yet to a lower extent probably due to the generally lower CD38 expression on CD8 ${ }^{+} \mathrm{T}$ cells (Fig. 1b; control 16.6\% \pm 9.7; Flu 20.2\% \pm 12.2 , $p=.461 ;$ Maf $12.5 \% \pm 5.0, p=.031$; FluMaf $3.6 \% \pm 3.1$, $p=.112$ ). When we compared the effect of cytotoxic treatment on absolute cell numbers, we found that $\mathrm{CD} 38^{+}$ $\mathrm{T}$ cells were more sensitive to mafosfamide-induced

Table 2 Viability (\%) and CLL/T cell ratio after 24 h cytotoxic treatment (Day 0) or subsequent 6 day culture in medium (Day 6)

\begin{tabular}{|c|c|c|c|c|}
\hline & $\mathrm{CD} 4^{+} \mathrm{T}$ cells & $\mathrm{CD}^{+} \mathrm{T}$ cells & CLL cells & CLL/T cell ratio \\
\hline \multicolumn{5}{|l|}{ Day 0} \\
\hline Medium & $91.2 \% \pm 1.8$ & $87.8 \% \pm 2.8$ & $68.9 \% \pm 5.0$ & $20.7 \pm 4.2$ \\
\hline Flu & $89.6 \% \pm 1.9 ; p=.204$ & $80.1 \% \pm 3.5 ; p=.135$ & $65.2 \% \pm 5.9 ; p=.421$ & $24.7 \pm 25.5 ; p=.155$ \\
\hline Maf & $91.9 \% \pm 1.7 ; p=.462$ & $85.2 \% \pm 3.8 ; p=.284$ & $68.5 \% \pm 6.7 ; p=.591$ & $19.1 \pm 4.5 ; p=.435$ \\
\hline FluMaf & $88.2 \% \pm 2.0 ; p=.024$ & $73.3 \% \pm 3.6 ; p<.001$ & $45.4 \% \pm 6.6 ; p=.022$ & $22.4 \pm 7.4 ; p=.432$ \\
\hline \multicolumn{5}{|l|}{ Day 6} \\
\hline Medium & $86.3 \% \pm 2.6$ & $80.1 \% \pm 4.2$ & $61.0 \% \pm 6.8$ & $15.9 \pm 2.9$ \\
\hline Flu & $40.3 \% \pm 5.6 ; p<.001$ & $26.6 \% \pm 5.7 ; p<.001$ & $35.1 \% \pm 6.6 ; p=.001$ & $43.9 \pm 9.9 ; p=.004$ \\
\hline Maf & $63.4 \% \pm 6.1 ; p<.001$ & $50.9 \% \pm 6.6 ; p<.001$ & $47.6 \% \pm 9.8 ; p=.015$ & $23.2 \pm 5.7 ; p=.027$ \\
\hline FluMaf & $15.8 \% \pm 4.7 ; p<.001$ & $6.4 \% \pm 2.7 ; p<.001$ & $5.7 \% \pm 7.2 ; p<.001$ & $65.6 \pm 16.4 ; p=.001$ \\
\hline
\end{tabular}

$P$ values reflect treatment compared to untreated medium control. Significant differences are highlighted in bold $(n=16)$ 
Fig. 1 PBMCs from 27 untreated CLL patients were incubated for $24 \mathrm{~h}$ with complete medium alone, fludarabine $(1 \mu \mathrm{g} / \mathrm{ml})$, mafosfamide $(1 \mu \mathrm{g} / \mathrm{ml})$ or both. The cells were then washed and cultured for subsequent 6 days in complete medium. On day 6 , the fraction of CD38-expressing $\mathrm{CD}^{+}(\mathbf{a})$ or $\mathrm{CD}^{+}(\mathbf{b}) \mathrm{T}$ cells was determined. $T$ cell subsets were defined as stated in the Results section and the fraction of memory $\mathrm{CD}^{+}(\mathbf{c})$ and $\mathrm{CD} 8^{+}$ (d) $\mathrm{T}$ cells was determined. Values significantly different from untreated controls are indicated by asterisks $(* p<.05$; $* * p<.01 ; * * * p<.001)$

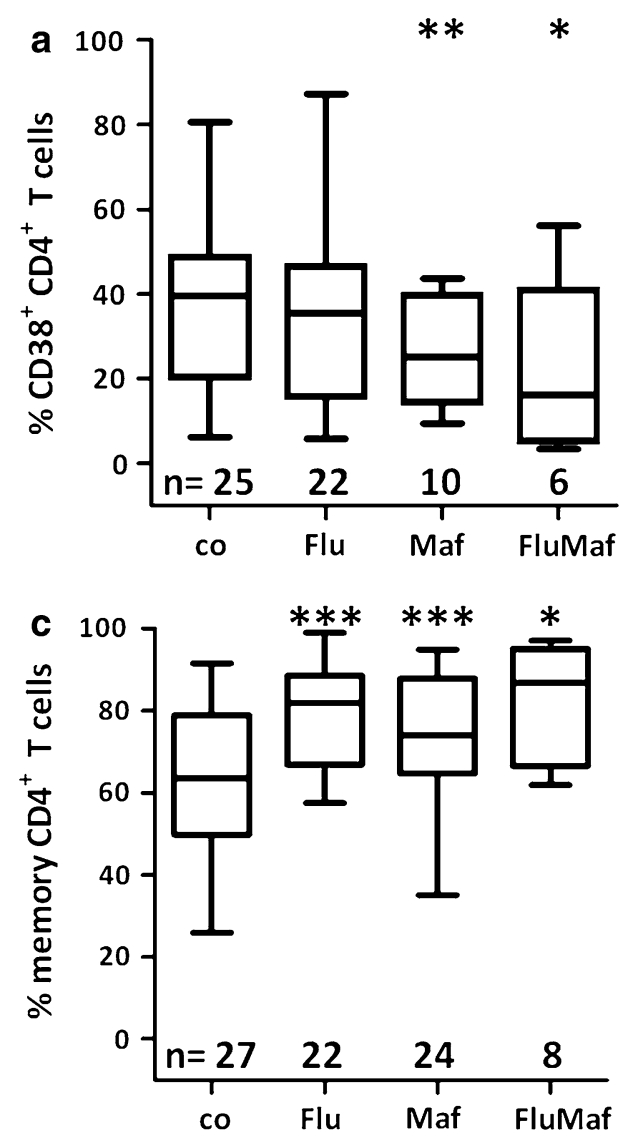

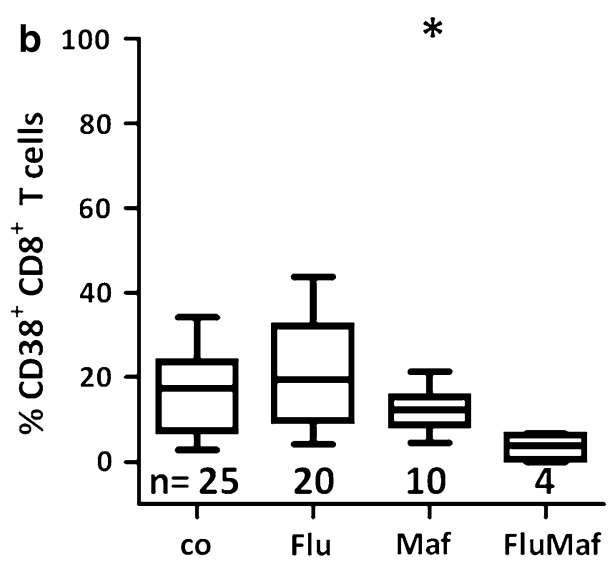

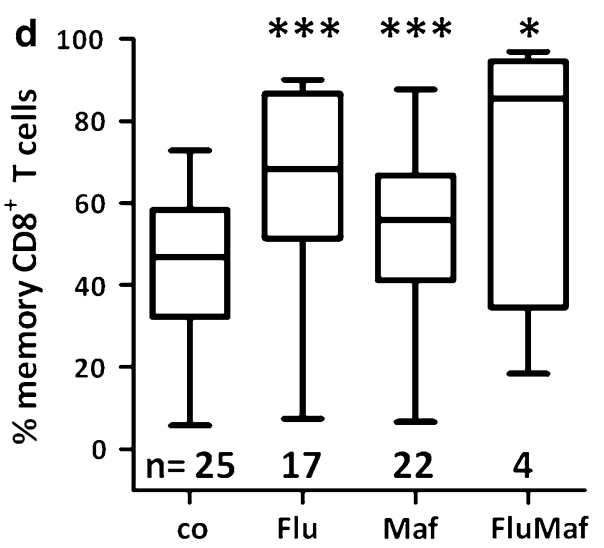

apoptosis than $\mathrm{T}$ cells lacking CD38 expression (not shown). None of the clinical risk parameters depicted in Table 1 correlated with altered CD38 expression on T cells after cytotoxic treatment.

Tregs were defined by high CD25 (IL-2R $\alpha$ ) and low CD127 (IL-7R $\alpha$ ) expression levels within the CD4 ${ }^{+} \mathrm{T}$ cell compartment. We found no significant changes in the percentage of Tregs after treatment with any of the cytotoxic agents alone or in combination (data not shown).

The expression profile of the leucocyte homing receptor L-selectin (CD62L) and CD45RA was used to distinguish between naïve $\left(\mathrm{CD} 45 \mathrm{RA}^{+}, \mathrm{CD} 2 \mathrm{~L}^{+}\right)$and memory $\left(\mathrm{CD}_{45 \mathrm{RA}^{-}}\right)^{\mathrm{T}}$ cells (Fig. 1c, d). When compared to untreated controls, fludarabine- or mafosfamide-treated $\mathrm{CD} 4^{+}$ $\mathrm{T}$ cells showed an elevated memory subset fraction $(63.3 \% \pm$ 16.4 vs. $79.3 \% \pm 13.0, p<.001$, or $73.1 \% \pm 15.8, p<.001$, respectively) that further increased following combined treatment with the two agents $(82.4 \% \pm 14.0, p=.016)$. Correspondingly, the percentage of naïve cells was decreased. In the $\mathrm{CD}^{+} \mathrm{T}$ cell compartment, a shift towards a memory phenotype could also be observed after cytotoxic treatment (control 45.6\% \pm 17.1 ; Flu 66.4\% $\pm 23.2, p<.001$; Maf $53.8 \% \pm 20.0, \quad p<.001 ; \quad$ FluMaf $71.5 \% \pm 35.9$, $p=.021)$.

Additionally, we evaluated the effect of fludarabine and mafosfamide on $\mathrm{T}$ cells from healthy donors. The effects observed in CLL $\mathrm{T}$ cells were recapitulated in the healthy $\mathrm{T}$ lymphocytes suggesting that these alterations are not disease-specific (Suppl. Fig. 2a-d).

Functionality of in vitro fludarabine-treated T cells: proliferation

To evaluate the ability of CLL T cells to proliferate following cytotoxic treatment, we performed MLR. PBMCs from 16 untreated CLL patients were incubated for $24 \mathrm{~h}$ with fludarabine or medium alone. The cells were then washed and co-cultured with allogeneic dendritic cells (DC) as stimulators and after 6 days $T$ cell proliferation rates were measured by the CFSE dilution assay.

Upon stimulation with DC, the proliferating fraction of fludarabine-treated $\mathrm{CD}^{+}$and $\mathrm{CD}^{+} \mathrm{T}$ cells was significantly higher than that of untreated $\mathrm{T}$ cells $(43.4 \% \pm 5.0$ vs. $25.7 \% \pm 5.1, p<.001$ and $40.9 \% \pm 6.7$ vs. $23.1 \% \pm$ $6.0, p<.001$, respectively) (Fig. 2a). To exclude the possibility that increased proliferation was just a phenomenon of increased stimulator:responder ratios due to the massive cytoreduction by fludarabine treatment, we correlated the proliferation rates after 6 days with the extent of cytoreduction by fludarabine. We could not observe any correlation between cell reduction by fludarabine treatment and proliferation induction by DC (not shown, Pearson correlation: 

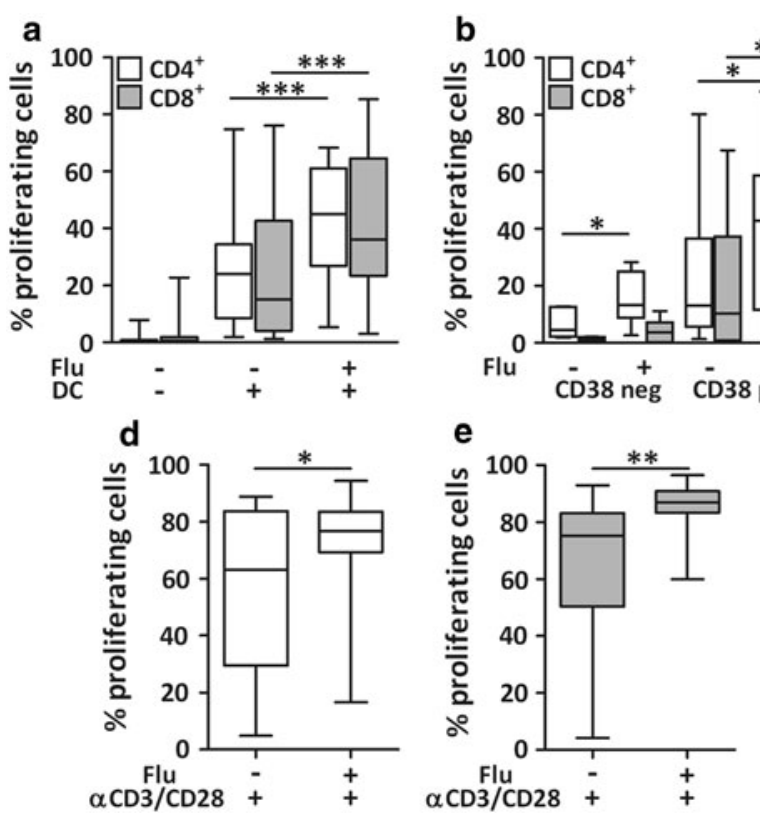
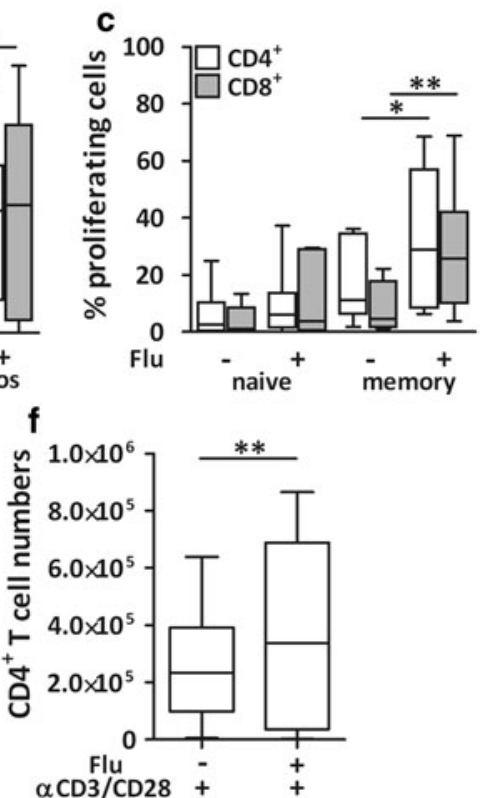

Fig. 2 a PBMCs from CLL patients $(n=16)$ were incubated for $24 \mathrm{~h}$ with medium alone, or fludarabine $(1 \mu \mathrm{g} / \mathrm{ml})$. The cells were then washed, stained with CFSE, and cultured for 6 days in the presence of allogeneic DC at a ratio of 10:1. On day 6, the fraction of CFSE-diluted $\mathrm{T}$ cells was assessed. The fraction of proliferating $\mathrm{T}$ cells in CD38-positive or negative $\mathrm{T}$ cell population $(\mathbf{b})$ and in naïve or memory $\mathrm{T}$ cell compartment (c) was measured $(n=8)$. d PBMCs from CLL patients $(n=16)$ were incubated for $24 \mathrm{~h}$ with medium alone, or fludarabine

0.216, $p=.389$ ), ruling out a bias generated by variable stimulator:responder ratios.

We next assessed the phenotype of the T cells expanding in response to DC stimulation and therefore characterized expression levels of CD38, CD62L and CD45RA on CD4 ${ }^{+}$ and $\mathrm{CD}^{+} \mathrm{T}$ cells on day 6 of the MLR. CD38-expressing T cells in general showed a higher proliferative activity than T cells not expressing CD38 (Fig. 2b). When PBMCs had been treated with fludarabine, increased proliferation was detected both in the $\mathrm{CD}^{+} \mathrm{CD}^{+} 8^{+}(26.5 \% \pm 10.1$ vs. $46.2 \% \pm 10.0, p=.024)$ and in the $\mathrm{CD} 4^{+} \mathrm{CD} 38^{-} \mathrm{T}$ cell pool $(7.3 \% \pm 1.9$ vs. $16.0 \% \pm 3.6, p=.031)$, whereas the increase in proliferation after fludarabine treatment was significant in the $\mathrm{CD}^{+} \mathrm{CD} 38^{+}$population $(21.4 \% \pm 9.5$ vs. $49.2 \% \pm 12.8, p=.011)$ and borderline significant in the $\mathrm{CD}^{+} \mathrm{CD}^{-} 8^{-} \mathrm{T}$ cell pool $(1.3 \% \pm 0.3$ vs. $4.7 \% \pm 1.5$, $p=.054)$. We also determined whether there was a difference in the capacity of naive and memory $\mathrm{T}$ cells to proliferate upon allogeneic stimulus after fludarabine treatment. We observed a significantly higher proportion of proliferating $\mathrm{T}$ cells in the memory compartment as compared to naïve $\mathrm{T}$ cells. Interestingly, naïve $\mathrm{T}$ cells showed no difference in proliferation after fludarabine treatment, whereas both $\mathrm{CD}^{+}$and $\mathrm{CD}^{+}$memory $\mathrm{T}$ cells, when pre-treated with fludarabine, showed higher proliferation than the respective untreated controls (Fig. $2 \mathrm{c}$; $\mathrm{CD}^{+}$: $16.0 \% \pm 5.2$
$(1 \mu \mathrm{g} / \mathrm{ml})$. The cells were then washed, stained with CFSE, and cultured for 6 days in the presence of beads coated with anti-CD3/antiCD28 antibodies at a PBMC/bead ratio of 250:1. On day 6, the fraction of CFSE-diluted $\mathrm{CD}^{+}(\mathbf{d})$ and $\mathrm{CD}^{+}(\mathbf{e}) \mathrm{T}$ cells and the total $\mathrm{CD} 4^{+} \mathrm{T}$ cell number (f) were assessed. Significance is indicated by asterisks $(* p<.05, * * p<.01, * * * p<.001)$ (white bars $\mathrm{CD} 4^{+}$, grey bars $\mathrm{CD} 8^{+}$ $\mathrm{T}$ cells)

vs. $34.0 \% \pm 9.9, \quad p=.030 ; \quad \mathrm{CD}^{+}: \quad 8.3 \% \pm 3.1 \quad$ vs. $29.7 \% \pm 8.3, p=.009)$. In order to confirm these results in a setting that is independent of allogeneic antigen recognition, we performed proliferation assays using beads coupled with $\alpha \mathrm{CD} 3$ and $\alpha \mathrm{CD} 28$ antibodies instead of allogeneic DC. The $\mathrm{CD}^{+}$and $\mathrm{CD}^{+} \mathrm{T}$ cell proliferation rate upon $\mathrm{CD} 3 / \mathrm{CD} 28$ bead stimulation was significantly higher when the cells were pretreated with fludarabine for $24 \mathrm{~h}$ (Fig. 2 d, e; $\mathrm{CD}^{+}$: $56.7 \% \pm 29.1$ vs. $74.5 \% \pm 17.8$, $p=.021 ; \mathrm{CD}^{+}: 63.1 \% \pm 27.7$ vs. $\left.84.9 \% \pm 9.4, p=.005\right)$. Additionally, absolute $\mathrm{CD}^{+} \mathrm{T}$ cells numbers after CD3/ CD28 bead stimulation were significantly increased in the fludarabine-pretreated samples $(p=.004)$, thus confirming and underlining the positive influence of fludarabine on $\mathrm{T}$ cell proliferation in an antigen-independent setting (Fig. 2f). Fludarabine-induced increase in $\mathrm{T}$ cell proliferation after CD3/CD28 beads was recapitulated in healthy T lymphocytes (Suppl. Fig. 2e, f).

Functionality of in vitro fludarabine-treated T cells: cytokine secretion

$\mathrm{T}_{\mathrm{H}}$ 1-type cytokines such as interferon gamma (IFN $\gamma$ ), interleukin 2 (IL-2) and tumour necrosis factor alpha (TNF $\alpha$ ) are considered key cytokines for $\mathrm{T}$ cell-mediated tumour control, while $\mathrm{T}_{\mathrm{H}} 2$ cytokines, as IL-10, IL-4 and IL-6, 
counteract differentiation of $\mathrm{T}$ cells to a $\mathrm{T}_{\mathrm{H}} 1$ subtype. We therefore investigated the ability of fludarabine- or mafosfamide-treated $\mathrm{T}$ cells to produce $\mathrm{T}_{\mathrm{H}} 1$ or $\mathrm{T}_{\mathrm{H}} 2$ cytokines upon stimulation with PMA/ionomycin.

We incubated PBMCs from untreated CLL patients with fludarabine $(1 \mu \mathrm{g} / \mathrm{ml})$, mafosfamide $(1 \mu \mathrm{g} / \mathrm{ml})$ or DMSO (medium control) for $24 \mathrm{~h}$. The cells were then washed and were left untreated or stimulated for additional 6 days with PMA $(1 \mathrm{ng} / \mathrm{ml})$ and ionomycin $(0.5 \mu \mathrm{g} / \mathrm{ml})$. We collected the culture supernatants and evaluated the concentration of secreted cytokines by CBA.

As depicted in Fig. 3, we found that after 6 days of stimulation with PMA/ionomycin, the supernatant of PBMCs pre-treated with fludarabine showed significantly elevated levels of the $\mathrm{T}_{\mathrm{H}} 1$ cytokines IFN $\gamma(p=.025)$ and IL-2 $(p=.024)$. Mafosfamide did not significantly alter the levels of the two $\mathrm{T}_{\mathrm{H}} 1$ cytokines IFN $\gamma(p=.065)$ and IL-2 $(p=.658)$. Furthermore, the $\mathrm{T}_{\mathrm{H}} 2$ cytokine IL-10 was significantly decreased in fludarabine- $(p=.016)$ but not in mafosfamide- $(p=.219)$ treated samples (Fig. 3). While $\mathrm{TNF} \alpha$ levels remained nearly unaffected when compared to untreated controls, IL-4 and IL-6 levels were either below the detection limit of the CBA or, in the samples where detection was possible, not significantly altered by either fludarabine or mafosfamide treatment (data not shown). To ascertain that the elevated $\mathrm{T}_{\mathrm{H}} 1$ cytokine levels originate from $\mathrm{T}$ cells and not from the CLL cells, we performed intracellular IFN $\gamma$ staining of PBMCs after $24 \mathrm{~h}$ fludarabine treatment followed by $4 \mathrm{~h}$ PMA/ionomycin stimulation. We did not detect intracellular IFN $\gamma$ in $\mathrm{CD} 19^{+} \mathrm{CD}^{+} \mathrm{CLL}$ cells, but IFN $\gamma$-positive cells within the $\mathrm{CD} 19^{-} \mathrm{CD}^{+} \mathrm{T}$ cell population (Suppl. Fig. 1).

Characterization of CLL T cells after in vivo fludarabine/ cyclophosphamide (FC) treatment

Since we observed changes in the T cell compartment after in vitro treatment of CLL PBMCs with fludarabine or mafosfamide with respect to activation status, differentiation, proliferation and cytokine secretion, we finally tested whether treatment in vivo would yield similar results. We therefore analyzed samples from chemonaïve CLL patients who started a modified FC therapy protocol at our clinical department. This protocol includes administration of fludarabine $\left(25 \mathrm{mg} / \mathrm{m}^{2} /\right.$ day i.v. $)$ and cyclophosphamide $(250 \mathrm{mg} /$ $\mathrm{m}^{2} /$ day i.v.) over 4 days. We used samples drawn before therapy (d0) and on day 1,2 and 3 of the first cycle for expression and functional studies.

For functional analysis of $\mathrm{T}$ cell proliferation we collected blood samples from FC-treated patients before treatment, purified the lymphocytes and incubated them in vitro for $24 \mathrm{~h}$ with or without $1 \mu \mathrm{g} / \mathrm{ml}$ fludarabine. In addition, PBMCs from samples drawn after 1 or 3 days of in vivo FC treatment were isolated. Cells were washed, stained with CFSE and co-cultured for subsequent 6 days with DC at a ratio 10:1. For each sample, the percentage of proliferating $\mathrm{T}$ cells was measured on day 6 of the co-culture period (Fig. 4a). When compared with untreated control cells, in vitro incubation with fludarabine increased the percentage of proliferating $\mathrm{CD}^{+}(15.9 \% \pm 5.3$ vs. $24.2 \% \pm 8.2, p=$ $.049)$ and $\mathrm{CD}^{+}(21.2 \% \pm 4.0$ vs. $58.6 \% \pm 3.8, p=.001) \mathrm{T}$ cells. While there was no increase in $\mathrm{T}$ cell proliferation after $24 \mathrm{~h}$ in vivo FC treatment, we detected increased fractions of proliferating $\mathrm{T}$ cells after 3 days in vivo $\mathrm{FC}$ treatment $\left(\mathrm{CD}^{+} 15.9 \% \pm 5.3\right.$ vs. $33.1 \% \pm 8.7, p=.010 ; \mathrm{CD}^{+}$ $21.2 \% \pm 4.0$ vs. $75.7 \% \pm 8.4, p=.003$ ).

We also compared expression of CD38 on CLL T cells on day 0 and day 3 of the therapy and observed a slight increase in $\mathrm{CD}^{+} \mathrm{CD} 38^{+}(54.3 \% \pm 2.8$ vs. $58.3 \% \pm 3.8$, $p=.387)$ and $\mathrm{CD} 8^{+} \mathrm{CD} 38^{+} \mathrm{T}$ cells $(51.1 \% \pm 4.2$ vs. $59.4 \pm 4.9, p=.210$ ) (Fig. 4b), that was not significant. The fraction of Tregs within the $\mathrm{CD} 4^{+} \mathrm{T}$ cells remained stable over the first 3 days of therapy (not shown). We finally evaluated any changes in $\mathrm{T}$ cell subset distribution between day 0 and day 3 of the FC treatment. The memory fraction remained stable or even slightly decreased during this
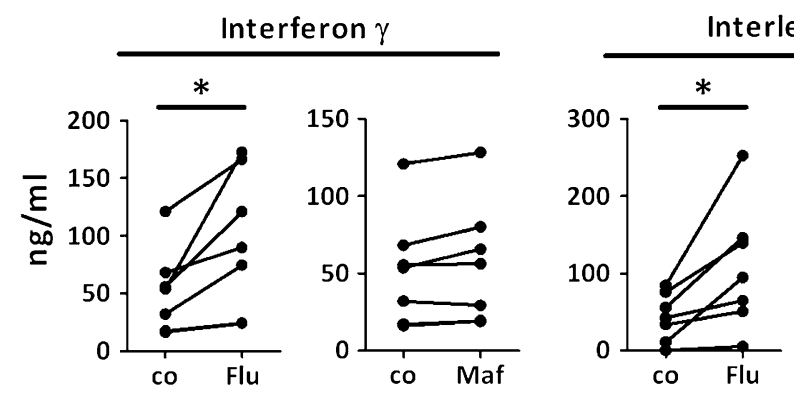

Fig. 3 PBMCs from seven untreated CLL patients were incubated with medium alone (co), fludarabine (Flu $1 \mu \mathrm{g} / \mathrm{ml}$ ) or mafosfamide (Maf $1 \mu \mathrm{g} / \mathrm{ml}$ ) for $24 \mathrm{~h}$. The cells were then washed and incubated for further 6 days in presence of PMA $(1 \mathrm{ng} / \mathrm{ml})$ and ionomycin $(0.5 \mu \mathrm{g} /$ $\mathrm{ml})$ at a concentration of $2.5 \times 10^{6}$ cells $/ \mathrm{ml}$. Culture supernatants were collected and the concentration of cytokines $(\mathrm{ng} / \mathrm{ml})$ was measured by cytokine bead assay $(C B A)$. Values significantly different from untreated controls are indicated by asterisks $(* p<.05)$ 
Fig. 4 a Chemonaïve CLL patients were treated with fludarabine and cyclophosphamide. PBMCs collected before treatment were incubated for $24 \mathrm{~h}$ in presence (vitro24) or absence of $1 \mu \mathrm{g} / \mathrm{ml}$ fludarabine. PBMCs were also collected on day 1 (vivo24) and day 3 (vivo72) of the FC treatment. All samples were co-cultured in vitro for 6 days with allogeneic DC and the $\mathrm{T}$ cell proliferation rates on day 6 were measured by CFSE dilution. Boxplots indicate the percentage of proliferating $\mathrm{CD}^{+}$(white bars) or $\mathrm{CD} 8^{+}$ (grey bars) T cells $(n=6)$. b-d Peripheral blood was collected before treatment $(0)$ and after 24 or $72 \mathrm{~h}$ of therapy ( $n=16)$. Whole blood staining was performed of each sample and the percentage of (b) $\mathrm{CD} 38^{+}$

$\mathrm{T}$ cells as well as the $\mathrm{T}$ cell subset distribution of (c) $\mathrm{CD} 4^{+}$ and (d) $\mathrm{CD}^{+} \mathrm{T}$ cells were determined by flow cytometry (naïve $\mathrm{T}$ cells in normal frames, memory $\mathrm{T}$ cells in bold frames)

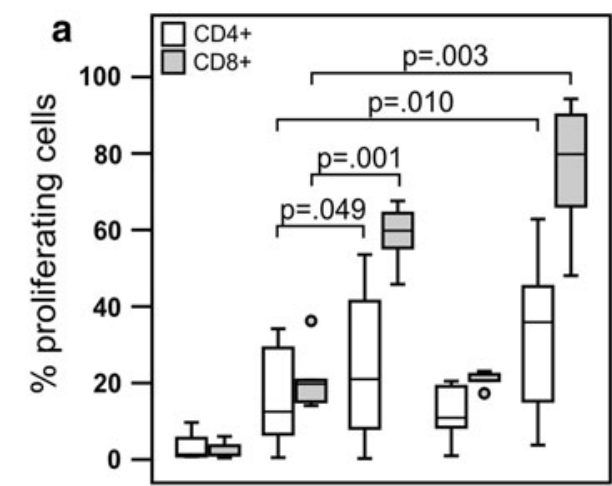

Fludarabine - $\quad$ - vitro24 vivo24 vivo72

DC $1: 10 \quad-\quad+\quad+\quad+\quad+$

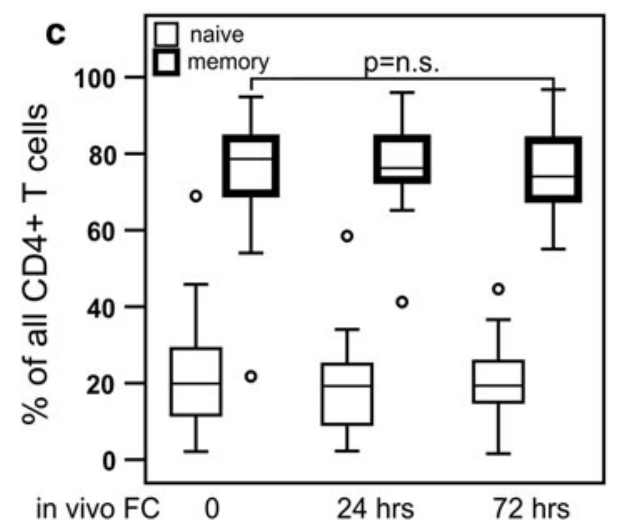

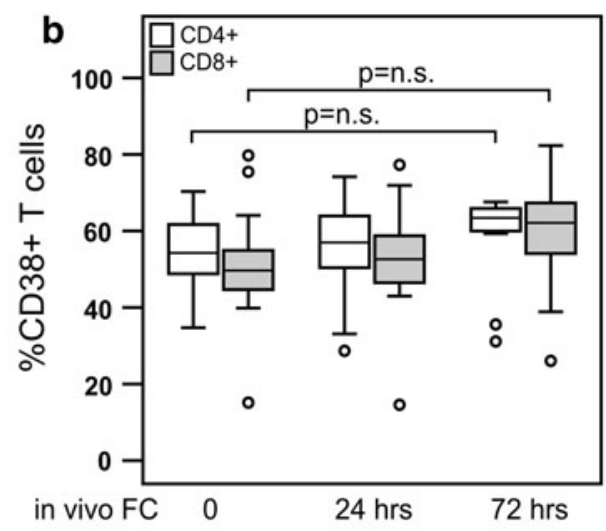

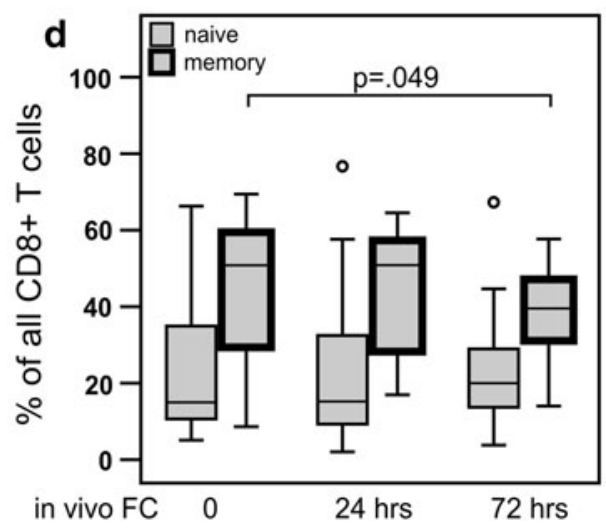

period in the $\mathrm{CD}^{+}$(Fig. $4 \mathrm{c}, 74.3 \% \pm 4.4$ vs. $60.9 \% \pm 7.9$, $p=.150$ ) and in the $\mathrm{CD}^{+}$(Fig. $4 \mathrm{~d}, 45.3 \% \pm 4.5$ vs. $31.6 \% \pm 4.9, p=.049) \mathrm{T}$ cell compartment.

Characterization of $\mathrm{T}$ cells after in vivo fludarabine treatment of tcll transgenic tumour transplanted mice

Since treatment of our patient cohort included administration of rituximab [29] on day 4 of therapy, possible long-term alterations in the $\mathrm{T}$ cell compartment following fludarabine/ cyclophosphamide treatment in vivo could not be assessed in these patients. Therefore, we used tclltg mice as a CLL mouse model to address this question. We transplanted primary tcl1tg tumour cells into syngeneic wildtype mice. At the onset of disease, we treated these mice with fludarabine and monitored changes in the peripheral $\mathrm{T}$ cell subsets. As shown in Fig. 5, we observed an increase in the percentage of cells with a memory phenotype within the $\mathrm{CD} 4^{+}$and the $\mathrm{CD}^{+} \mathrm{T}$ cell compartment (memory $\mathrm{CD} 4^{+}: \mathrm{d}-3,42.9 \pm 13.7$; d3, $70.0 \pm 14.6, p<.001 ; \mathrm{d} 7,74.3 \pm 15.6, p<.001 ; \mathrm{d} 11$, $60.2 \pm 33.9, p=.338$; memory $\mathrm{CD}^{+}: \mathrm{d}-3,57.6 \pm 13.2 ; \mathrm{d} 3$, $87.2 \pm 5.2, \quad p=.002 ; \quad \mathrm{d} 7, \quad 80.2 \pm 6.3, \quad p=.002 ; \quad \mathrm{d} 11$, $81.5 \pm 9.9, p<.001)$ In addition and in line with the results from our in vitro study of the human model, the absolute numbers of $T_{H} 1$ cells increased during treatment while $T_{H} 2$ cell numbers declined (Fig. 5c).

\section{Discussion}

Chemoimmunotherapy of lymphatic malignancies aims at the reduction of tumour load on the one hand and establishment of long-lasting tumour control by the patient's immune system on the other. Studies in patients with refractory metastatic melanoma have recently shown that lymphodepletion, induced by fludarabine/cyclophosphamide treatment, is associated with increased serum levels of the lymphocyte homeostatic cytokines IL-7 and IL-15, and that subsequent adoptive cell therapy can mediate significant tumour regression [30, 31]. Here, we show that cytotoxic treatment with fludarabine despite its negative impact on lymphocyte numbers in vitro and in vivo positively interacts with $\mathrm{T}$ cell functions, and that some of these effects synergize with cyclophosphamide, a combination used as backbone of modern CLL treatment.

We observed that $\mathrm{CD}^{+}{ }^{+} \mathrm{CD} 38^{+} \mathrm{T}$ cells exhibited a higher sensitivity to in vitro treatment with fludarabine/ mafosfamide than the $\mathrm{CD} 38^{-} \mathrm{T}$ cell counterpart, resulting in a decrease in percentage of $\mathrm{CD} 38^{+} \mathrm{CD} 4^{+} \mathrm{T}$ cells. $\mathrm{CD} 38$ expression on $\mathrm{T}$ cells has been shown to reflect chronic activation and stimulation in various diseases $[32,33]$ and also in acute graft rejection [34]. Our own group has recently shown that the levels of CD38 expression on $\mathrm{T}$ cells predict the course of the disease in male CLL patients 

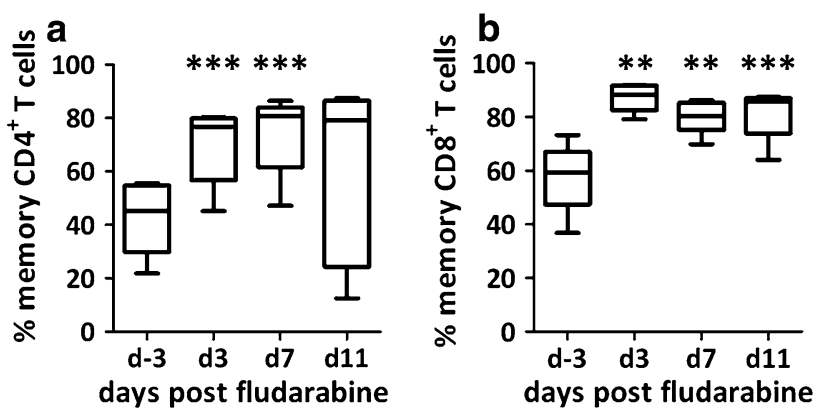

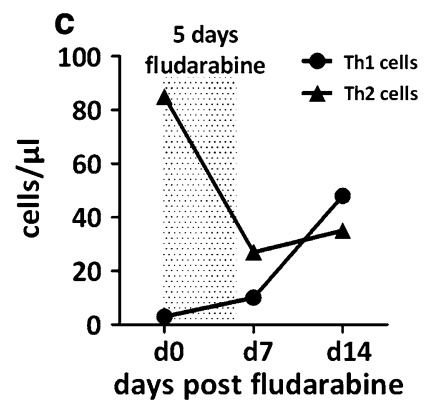

Fig. 5 a Peripheral blood from five mice was collected 3 days prior to (d-3), during (d3) and after (d7, d11) fludarabine treatment (5 days; $35 \mathrm{mg} / \mathrm{kg} /$ day). $\mathrm{T}$ cells were stained using specific antibodies and the percentage of $\mathrm{CD}^{+}(\mathbf{a})$ and $\mathrm{CD}^{+}(\mathbf{b})$ memory $\mathrm{T}$ cells was assessed.

with higher CD38 expression correlating with a worse clinical prognosis [35], and this was confirmed by the recent study by Abousamra et al. [36]. According to these data, $\mathrm{CD} 38^{+} \mathrm{T}$ cells, despite their activated phenotype, seem to fail to perform sufficient tumour control in CLL but rather support maintenance or even expansion of the malignant clone. Hence, preferential depletion of $\mathrm{CD} 38^{+} \mathrm{T}$ cells during FC treatment as observed in this study in vitro could well add to the therapeutic efficacy of this drug combination in CLL.

Furthermore, we observed that $\mathrm{CD} 4^{+}$and $\mathrm{CD} 8^{+}$memory $\mathrm{T}$ cells were more resistant than naïve $\mathrm{T}$ cells to fludarabine and mafosfamide treatment in vitro leading to a decrease in the naïve/memory $\mathrm{T}$ cell ratio. These results are in line with data from Koike et al. [37] who have shown in a melanoma mouse model that adoptively transferred naïve $T$ cells displayed an activated memory phenotype after lymphodepletion with cyclophosphamide and fludarabine. Additionally, in psoriatic arthritis and multiple sclerosis, increased resistance of memory $\mathrm{T}$ cells towards fludarabine or cyclophosphamide has been shown [38, 39]. Interestingly, when we stimulated CLL PBMCs after fludarabine treatment with $\mathrm{DC}$ or $\mathrm{CD} 3 / \mathrm{CD} 28$ beads, we observed an increase in $\mathrm{T}$ cell proliferation as compared to untreated control PBMCs. The increase in proliferation was mainly found in the memory $\mathrm{T}$ cell subpopulations and was only observed after fludarabine treatment, while mafosfamide, although inducing similar levels of apoptosis, had no effect on proliferation rates (data not shown). Since cytotoxic therapy not only reduces the tumour load but also a significant proportion of immune cells involved in tumour control, rapid reconstitution of the $\mathrm{T}$ cell compartment after therapy seems crucial in order to reduce the chance for cancer relapse. Fludarabine, by enhancing the proliferative capacity especially of memory $\mathrm{T}$ cells, might thereby contribute positively to long-lasting tumour control.

Gamberale et al. [40] have shown that IFN $\gamma$ production upon PMA/ionomycin stimulation of $\mathrm{CD} 2^{+} \mathrm{T}$ and NK cells c In a separate experiment, the numbers of peripheral blood $\mathrm{T}_{\mathrm{H}} 1$ and $\mathrm{T}_{\mathrm{H}} 2 \mathrm{CD}^{+} \mathrm{T}$ cells prior to (d0) and after fludarabine treatment ( $\left.\mathrm{d} 7, \mathrm{~d} 14\right)$ were determined. One representative result of two experiments is shown

from CLL patient samples or healthy donor lymphocytes was significantly increased after $24 \mathrm{~h}$ when fludarabine was added to the culture. Additionally, they showed that fludarabine did not reduce STAT1 expression, which is activated in response to IFN $\gamma$, in PBMCs or $\mathrm{CD} 2^{+}$cells from CLL patients or healthy donors, contrary to what had been reported before [41]. When we tested $\mathrm{T}$ cell functionality from CLL patients we also found that fludarabine treatment enhances the capacity of PBMCs to produce IFN $\gamma$ upon PMA/ionomycin stimulation. Yet, we only observed a significant increase of secreted IFN $\gamma$ after a 6 days post-treatment culture. This is probably due to the lower percentage of $\mathrm{T}$ cells $(8.4 \% \pm 2.4)$ in our analysed CLL samples when compared to the samples analysed by Gamberale et al. [40] (at least $15 \% \mathrm{CD} 2+$ cells). In extend to that, we could show that in vitro treatment with fludarabine, but not mafosfamide enhanced the production of the $\mathrm{T}_{\mathrm{H}} 1$ cytokine IL- 2 as well, whereas the $\mathrm{T}_{\mathrm{H}} 2$ cytokine IL-10 was decreased, indicating that in our experimental setting fludarabine promoted $\mathrm{T}_{\mathrm{H}} 1$ differentiation during $\mathrm{T}$ cell activation.

Notably, the observed $\mathrm{T}$ cell alterations occurred irrespective of the initial CLL/T cell ratio and were also recapitulated in $\mathrm{T}$ cells from healthy donors.

In contrast to what we found in our in vitro model, no changes in the ratios of memory/naïve or regulatory $\mathrm{T}$ cells could be observed in patients in vivo and also the fraction of $\mathrm{CD} 38^{+} \mathrm{T}$ cells was stable. Protection from apoptosis provided by the micro-environment in vivo might be responsible for this discrepancy. Alternatively, treatment for a longer period would be necessary to reveal the modulating effect of fludarabine on $T$ cell subsets in vivo.

The results from the tclltg mouse model in which we could follow possible $\mathrm{T}$ cell changes for up to 14 days after in vivo fludarabine treatment corroborate our results from the in vitro model and thereby support the time factor as one possible explanation. Also, when we stimulated PBMCs from CLL patients treated with fludarabine and cyclophosphamide for 3 days with DC, we again observed 
a significant increase in $\mathrm{T}$ cell proliferation when compared with non-treated samples. This indicates that FC treatment lowers the threshold for subsequent $\mathrm{T}$ cell expansion by other means than selective cytodepletion.

In conclusion, our results provide new evidence that fludarabine is not only cytotoxic but also able to modulate distinct functions of the immune system, in particular to stimulate a shift from naïve to memory $T$ cell subsets, to lower the threshold for proliferation and to increase $T_{H} 1$ cytokine production. Hence, besides reducing the tumour load, fludarabine-induced immune modulation may on the one hand improve post-treatment tumour control, but on the other hand also account for the observation that fludarabine mono- or combinational therapy increases the incidence of auto-immune reactions, predominantly autoimmune haemolytic anaemia [42, 43].

Acknowledgments We thank Lucia Haginger for the skilful preparation of CLL patient samples. This work was supported by the Klinische Malignom-und Zytokinforschung Salzburg-Innsbruck GmbH, grants of the Austrian Science Foundation (SFB021-P11 to R. Greil, P16153 to I.T., P19481-B12 to A.E., L488-B13 to A.E.), the Austrian National Bank (13420 to T.N.H., 10990 to A.E.) and the Province of Salzburg (to R. Greil).

Open Access This article is distributed under the terms of the Creative Commons Attribution Noncommercial License which permits any noncommercial use, distribution, and reproduction in any medium, provided the original author(s) and source are credited.

\section{References}

1. Finn OJ (2008) Cancer immunology. N Engl J Med 358:27042715

2. Tam CS, Keating MJ (2007) Chemoimmunotherapy of chronic lymphocytic leukemia. Best Pract Res Clin Haematol 20:479-498

3. Lake RA, Robinson BW (2005) Immunotherapy and chemotherapy-a practical partnership. Nat Rev Cancer 5:397-405

4. Zitvogel L, Apetoh L, Ghiringhelli F, Andre F, Tesniere A, Kroemer G (2008) The anticancer immune response: indispensable for therapeutic success? J Clin Invest 118:1991-2001

5. Baxevanis CN, Perez SA, Papamichail M (2009) Combinatorial treatments including vaccines, chemotherapy and monoclonal antibodies for cancer therapy. Cancer Immunol Immunother $58: 317-324$

6. Dunussi-Joannopoulos K (2002) The combination of chemotherapy and systemic immunotherapy and the concept of cure in murine leukemia and lymphoma. Leuk Lymphoma 43:20752082

7. Frey AB, Monu N (2008) Signaling defects in anti-tumor T cells. Immunol Rev 222:192-205

8. Tinhofer I, Marschitz I, Kos M, Henn T, Egle A, Villunger A, Greil R (1998) Differential sensitivity of CD4+ and CD8+ T lymphocytes to the killing efficacy of Fas (Apo-1/CD95) ligand+ tumor cells in B chronic lymphocytic leukemia. Blood 91:4273-4281

9. Frydecka I, Kosmaczewska A, Bocko D, Ciszak L, Wolowiec D, Kuliczkowski K, Kochanowska I (2004) Alterations of the expression of T-cell-related costimulatory CD28 and downregulatory CD152 (CTLA-4) molecules in patients with B-cell chronic lymphocytic leukaemia. Br J Cancer 90:2042-2048
10. Scrivener S, Goddard RV, Kaminski ER, Prentice AG (2003) Abnormal T-cell function in B-cell chronic lymphocytic leukaemia. Leuk Lymphoma 44:383-389

11. Ramsay AG, Johnson AJ, Lee AM, Gorgun G, Le Dieu R, Blum W, Byrd JC, Gribben JG (2008) Chronic lymphocytic leukemia T cells show impaired immunological synapse formation that can be reversed with an immunomodulating drug. J Clin Invest 118:2427-2437

12. Beyer M, Kochanek M, Darabi K, Popov A, Jensen M, Endl E, Knolle PA, Thomas RK, Bergwelt-Baildon M, Debey S, Hallek M, Schultze JL (2005) Reduced frequencies and suppressive function of $\mathrm{CD} 4+\mathrm{CD} 25$ hi regulatory $\mathrm{T}$ cells in patients with chronic lymphocytic leukemia after therapy with fludarabine. Blood 106:2018-2025

13. Motta M, Rassenti L, Shelvin BJ, Lerner S, Kipps TJ, Keating MJ, Wierda WG (2005) Increased expression of CD152 (CTLA-4) by normal $\mathrm{T}$ lymphocytes in untreated patients with B-cell chronic lymphocytic leukemia. Leukemia 19:1788-1793

14. Morrison VA (1998) The infectious complications of chronic lymphocytic leukemia. Semin Oncol 25:98-106

15. O'Brien S (1998) Clinical challenges in chronic lymphocytic leukemia. Semin Hematol 35:22-26

16. Hallek M, Schmitt B, Wilhelm M, Busch R, Krober A, Fostitsch HP, Sezer O, Herold M, Knauf W, Wendtner CM, Kuse R, Freund M, Franke A, Schriever F, Nerl C, Dohner H, Thiel E, Hiddemann W, Brittinger G, Emmerich B (2001) Fludarabine plus cyclophosphamide is an efficient treatment for advanced chronic lymphocytic leukaemia (CLL): results of a phase II study of the German CLL Study Group. Br J Haematol 114:342-348

17. Schmitt B, Wendtner CM, Bergmann M, Busch R, Franke A, Pasold R, Schlag R, Hopfinger G, Hiddemann W, Emmerich B, Hallek M (2002) Fludarabine combination therapy for the treatment of chronic lymphocytic leukemia. Clin Lymphoma 3:26-35

18. Bosch F, Ferrer A, Lopez-Guillermo A, Gine E, Bellosillo B, Villamor N, Colomer D, Cobo F, Perales M, Esteve J, Altes A, Besalduch J, Ribera JM, Montserrat E (2002) Fludarabine, cyclophosphamide and mitoxantrone in the treatment of resistant or relapsed chronic lymphocytic leukaemia. Br J Haematol 119:976984

19. Keating MJ, O’Brien S, Albitar M, Lerner S, Plunkett W, Giles F, Andreeff M, Cortes J, Faderl S, Thomas D, Koller C, Wierda W, Detry MA, Lynn A, Kantarjian H (2005) Early results of a chemoimmunotherapy regimen of fludarabine, cyclophosphamide, and rituximab as initial therapy for chronic lymphocytic leukemia. J Clin Oncol 23:4079-4088

20. Tsimberidou AM, Tam C, Abruzzo LV, O'Brien S, Wierda WG, Lerner S, Kantarjian HM, Keating MJ (2009) Chemoimmunotherapy may overcome the adverse prognostic significance of $11 \mathrm{q}$ deletion in previously untreated patients with chronic lymphocytic leukemia. Cancer 115:373-380

21. Foon KA, Boyiadzis M, Land SR, Marks S, Raptis A, Pietragallo L, Meisner D, Laman A, Sulecki M, Butchko A, Schaefer P, Lenzer D, Tarhini A (2009) Chemoimmunotherapy with low-dose fludarabine and cyclophosphamide and high dose rituximab in previously untreated patients with chronic lymphocytic leukemia. J Clin Oncol 27:498-503

22. Brode S, Cooke A (2008) Immune-potentiating effects of the chemotherapeutic drug cyclophosphamide. Crit Rev Immunol 28:109-126

23. Robak T, Korycka A, Kasznicki M, Wrzesien-Kus A, Smolewski $\mathrm{P}$ (2005) Purine nucleoside analogues for the treatment of hematological malignancies: pharmacology and clinical applications. Curr Cancer Drug Targets 5:421-444

24. Rai KR, Sawitsky A, Cronkite EP, Chanana AD, Levy RN, Pasternack BS (1975) Clinical staging of chronic lymphocytic leukemia. Blood 46:219-234 
25. Bichi R, Shinton SA, Martin ES, Koval A, Calin GA, Cesari R, Russo G, Hardy RR, Croce CM (2002) Human chronic lymphocytic leukemia modeled in mouse by targeted TCL1 expression. Proc Natl Acad Sci USA 99:6955-6960

26. Johnson AJ, Lucas DM, Muthusamy N, Smith LL, Edwards RB, De Lay MD, Croce CM, Grever MR, Byrd JC (2006) Characterization of the TCL-1 transgenic mouse as a preclinical drug development tool for human chronic lymphocytic leukemia. Blood 108:1334-1338

27. Holler C, Pinon JD, Denk U, Heyder C, Hofbauer S, Greil R, Egle A (2009) PKCbeta is essential for the development of chronic lymphocytic leukemia in the TCL1 transgenic mouse model: validation of PKCbeta as a therapeutic target in chronic lymphocytic leukemia. Blood 113:2791-2794

28. Bellosillo B, Villamor N, Colomer D, Pons G, Montserrat E, Gil J (1999) In vitro evaluation of fludarabine in combination with cyclophosphamide and/or mitoxantrone in B-cell chronic lymphocytic leukemia. Blood 94:2836-2843

29. McLaughlin P, Grillo-Lopez AJ, Link BK, Levy R, Czuczman MS, Williams ME, Heyman MR, Bence-Bruckler I, White CA, Cabanillas F, Jain V, Ho AD, Lister J, Wey K, Shen D, Dallaire BK (1998) Rituximab chimeric anti-CD20 monoclonal antibody therapy for relapsed indolent lymphoma: half of patients respond to a four-dose treatment program. J Clin Oncol 16:2825-2833

30. Dudley ME, Wunderlich JR, Yang JC, Sherry RM, Topalian SL, Restifo NP, Royal RE, Kammula U, White DE, Mavroukakis SA, Rogers LJ, Gracia GJ, Jones SA, Mangiameli DP, Pelletier MM, Gea-Banacloche J, Robinson MR, Berman DM, Filie AC, Abati A, Rosenberg SA (2005) Adoptive cell transfer therapy following non-myeloablative but lymphodepleting chemotherapy for the treatment of patients with refractory metastatic melanoma. J Clin Oncol 23:2346-2357

31. Dudley ME, Yang JC, Sherry R, Hughes MS, Royal R, Kammula U, Robbins PF, Huang J, Citrin DE, Leitman SF, Wunderlich J, Restifo NP, Thomasian A, Downey SG, Smith FO, Klapper J, Morton K, Laurencot C, White DE, Rosenberg SA (2008) Adoptive cell therapy for patients with metastatic melanoma: evaluation of intensive myeloablative chemoradiation preparative regimens. J Clin Oncol 26:5233-5239

32. Pavon EJ, Munoz P, Navarro MD, Raya-Alvarez E, CallejasRubio JL, Navarro-Pelayo F, Ortego-Centeno N, Sancho J, Zubiaur M (2006) Increased association of CD38 with lipid rafts in T cells from patients with systemic lupus erythematosus and in activated normal T cells. Mol Immunol 43:1029-1039
33. Savarino A, Bottarel F, Malavasi F, Dianzani U (2000) Role of CD38 in HIV-1 infection: an epiphenomenon of T-cell activation or an active player in virus/host interactions? AIDS 14:1079-1089

34. Boleslawski E, BenOthman S, Grabar S, Correia L, Podevin P, Chouzenoux S, Soubrane O, Calmus Y, Conti F (2008) CD25, CD28 and CD38 expression in peripheral blood lymphocytes as a tool to predict acute rejection after liver transplantation. Clin Transpl 22:494-501

35. Tinhofer I, Rubenzer G, Holler C, Hofstaetter E, Stoecher M, Egle A, Steurer M, Greil R (2006) Expression levels of CD38 in T cells predict course of disease in male patients with B-chronic lymphocytic leukemia. Blood 108:2950-2956

36. Abousamra NK, El Din MS, Azmy E (2009) T-cell CD38 expression in B-chronic lymphocytic leukaemia. Hematol Oncol 27:82-89

37. Koike N, Pilon-Thomas S, Mule JJ (2008) Nonmyeloablative chemotherapy followed by T-cell adoptive transfer and dendritic cellbased vaccination results in rejection of established melanoma. J Immunother 31:402-412

38. Gladstone DE, Golightly MG, Brannagan TH III (2007) High dose cyclophosphamide preferentially targets naive $\mathrm{T}$ (CD45/CD4/ RA+) cells in CIDP and MS patients. J Neuroimmunol 190:121126

39. Takada K, Danning CL, Kuroiwa T, Schlimgen R, Tassiulas IO, Davis JC Jr, Yarboro CH, Fleisher TA, Boumpas DT, Illei GG (2003) Lymphocyte depletion with fludarabine in patients with psoriatic arthritis: clinical and immunological effects. Ann Rheum Dis 62:1112-1115

40. Gamberale R, Fernandez-Calotti P, Sanchez-Avalos J, Alberto MF, Geffner J, Giordano M (2006) The effect of fludarabine on interferon-gamma production by lymphoid cells from healthy donors and patients with B-cell chronic lymphocytic leukemia. Haematologica 91:574-576

41. Frank DA, Mahajan S, Ritz J (1999) Fludarabine-induced immunosuppression is associated with inhibition of STAT1 signaling. Nat Med 5:444-447

42. Dearden C, Wade R, Else M, Richards S, Milligan D, Hamblin T, Catovsky D (2008) The prognostic significance of a positive direct antiglobulin test in chronic lymphocytic leukemia: a beneficial effect of the combination of fludarabine and cyclophosphamide on the incidence of hemolytic anemia. Blood 111:1820-1826

43. Steurer M, Pall G, Richards S, Schwarzer G, Bohlius J, Greil R (2006) Purine antagonists for chronic lymphocytic leukaemia. Cochrane Database Syst Rev 3:CD004270 